\title{
Explaining Franchisor's Tendency To Use Multi-Unit Franchising: Development Of A Theoretical Model
}

Dildar Hussain, University of Vienna, Austria

Muhammad Zafar Yaqub, University of Vienna, Austria

\begin{abstract}
In this theoretical paper, we give an overview of the development of literature on multi-unit franchising, discuss the theoretical and methodological deficits, and develop a model for empirical test. The main focus of existing franchising research has been on single unit franchising. Although several empirical studies were published on multi-unit franchising in the last decade, the research deficit primarily results from the lack of theoretical foundation of this ownership strategy in franchising networks. As an attempt to address this research gap, we develop an integrative model. The propositions explain the franchisor's tendency to use multi-unit franchising in context of transaction cost theory (franchisee's specific investments and market uncertainty), resource based view (financial resources scarcity), organizational capabilities view (local market knowhow and system specific assets) and agency theory (behavioral uncertainty). We plan to empirically test the proposed model in the near future.
\end{abstract}

Keywords: Multi-unit Franchising, Agency Theory, Transaction Cost theory, Resource Based and Organization Capabilities View, Conceptual Model

\section{INTRODUCTION}

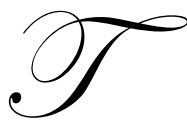

he use of franchising is continuously growing throughout the world and its role in national economies is becoming more important (Kaufmann and Dant 1996). Almost half of the retail goods in the USA are distributed through franchise systems (Business Week 2000) and franchising is the fastest growing form of retailing (Dant et al. 2007). A major portion of recent growth in the franchising business can be attributed to the emergence of multi-unit franchising (Gruenhagen and Dorsch 2003; Kaufmann 1992). Research is evident that almost half of the franchised units in the USA are operated by multi-unit franchisees (Wardsworth and Morgan 2003).

When a firm decides to expand the number of its retail outlets, it has two options. Either it can own a new outlet unit or it can franchise. Franchising can be done either by selecting a new franchisee or by selection of one of the existing franchisees to operate the new unit, which would result into multi-unit franchising. A multi-unit franchisee can be defined as a firm or a person that owns two or more units at multiple geographic locations in the same franchise system (Kalnins and Mayer 2004). The phenomenon of multi-unit franchising can be divided into two types; i.e. sequential multi-unit franchising and area development multi-unit franchising (Kaufmann and Dant 1996). In the first type, one of the existing franchisees is granted a right to open the additional outlets and each of the outlets is governed by separate franchising contract (Gruenhagen and Mittelstaedt 2005). On the other hand, in the second type of arrangement, the franchisee is selected as an area developer and is obliged to open a certain number of branches/outlets in a particular geographical area during a specific time period as stipulated in the franchise contract. The area developers often get the exclusivity in that particular area (Kaufmann and Kim 1995).

In the past, the main focus of franchising research has been on single-unit franchising. Kaufmann (1996) noted that there is need for a new direction in franchising research. He argues "...the metaphor used by most 
franchising researchers, no matter what their discipline, has been the single unit franchisee. It takes little by way of causal empirical observation to belie that assumption. Single-unit franchisees are the exception, not the rule."

Although several empirical studies were published on multi-unit franchising in the last decade, the research deficit primarily results from the lack of theoretical foundation of this ownership strategy in franchising networks. Our goal in this conceptual article is first to give an overview of the development of the literature on multi-unit franchising, second to analyze the empirical studies in the light of agency theory, resource-based view and transaction cost theory, and third to develop a model for empirical research in the future.

\section{REVIEW OF MULTI-UNIT FRANCHISING LITERATURE}

There number of studies available in the specific area of multi-unit franchising is limited and a significant proportion of these studies are either theoretical or exploratory in nature. In this section, we review the important empirical studies relevant to multi-unit franchising.

Wadsworth and Morgan (2003) find that about 20\% of franchisees hold more than one unit and they operate more than half of total outlets. Some industries use multi-unit franchising more extensively as compared to others. These include fast food, automotive, restaurant, and retail food, etc. Zeller et al (1980) reveal that multi-unit franchising results in reduced management problems as the franchisor has to deal with fewer multi-unit franchisees as compared to a large number of single-unit franchisees. Robicheaux, Dant and Kaufmann (1994) show that use of area development agreements varies among various sectors of fast food industry and that the franchisors, who expect management problems with multi-unit operations, have a relatively lower proportion of area development agreements. The findings by Kaufmann (1992) reveal that area developments have lower performance among all four strategies simulated in his paper and that the sequential allocation strategies may perform better as compared to single unit strategy. A study by Kaufmann \& Kim (1995) finds a positive relationship between use of multi-unit franchising and system growth rate. Kaufmann and Dant (1996) also confirmed the positive relationship between multi-unit franchising and growth rate.

Kaufmann and Dant (1998) argue that franchisors are reluctant to place their business concept in the hands of new and untested franchisees; therefore, they look toward existing franchisees to grant new units. On the other hand, it has been empirically evidenced that franchisors believe that it is less risky to allocate new units to existing franchisees rather than new and untested franchise partners (Bradach 1995). The author finds, after analyzing the responses of the top executives, that multi-unit franchising can address certain issues in a more effective way as compared to single-unit franchising, particularly the issues related to unit growth and system-wide adaptation. It has also been empirically supported that the new units which are allotted to existing franchisees have lower risk of failure (Bates 1998). Franchisors use multi-unit franchising as a measure to mitigate the risk of opportunistic behavior of the franchisee (Bercovitz 2003). The results support the propositions that multi-unit franchising reduces the system terminations and system litigations rate.

Kalnins \& Lafontaine (2004) investigate the question about how new units are allocated to franchisees. They find that the franchisors prefer existing franchisors to allocate the new units, particularly to those who presently operate unit(s) close to the proposed location of the new unit. Kalnins \& Mayer (2004) confirm that local knowledge gathered by the franchisee plays an important role for success of subsequent units opened in the same geographical area. According to the results of Gruenhagen and Mittlestaedt (2005), the area developer multi-unit franchisees reported that they considered (at the time of taking up franchise agreement) their venture as an investment. On the other hand, sequential multi-unit franchisees reported that they were mainly motivated by their entrepreneurial ambitions. Garg et al. (2005) investigate the factors that influence the franchisor's choice of adoption of multi-unit franchising and area development agreements. The data indicate that the franchisors that plan for expansions are more likely to use multi-unit franchising. The results also suggested that the franchisors that place more emphasis on uniformity are more likely to use a relatively higher proportion of area development agreements rather than sequential multi-unit franchising.

Weaven and Frazer (2004) empirically verify a positive relationship between multi-unit franchising and system maturity by investigating the Australian franchise sector. The authors proposed a negative relationship 
between multi-unit franchising and level of conflict in the franchise system, but the analysis of data revealed that there is a significant positive relationship between the level of conflict and multi-unit franchising. These results contradict the findings by Bercovitz (2003) from the US market where she found a negative relationship between multi-unit franchising and litigation and system termination rates. The contradiction of results could be attributed to the fact that both studies were carried out in different markets. Weaven \& Frazer (2006) investigate the motivational factors of single unit and multi-unit franchisees. The findings suggest that single-unit franchisees consider marketing strength of the franchisor brand, potential to employ family members, initial training days, and the level of operational freedom to assess the franchise offer. On the other hand, multi-unit franchisees place more emphasis on the importance of business vision and concept, potential for expansion, ongoing training, involvement in the decision-making process, and governance structure. Weaven and Frazer (2007a) reveal that the franchisor who perceives higher agency costs in the future tend to use a higher proportion of multi-unit franchising. The positive relationship between adoption of multi-unit franchising and (1) system uniformity and (2) higher brand value was also found significant. Furthermore, the findings of an empirical study in Australia by Weaven \& Frazer (2007b) suggest a positive relationship between multi-unit franchising and age and size of the franchise system, system corporatization, and use of plural forms of distribution. The negative relationship between the level of conflict and multi-unit franchising has also been evidenced empirically.

The analysis of empirical data from the Spanish franchise sector shows that multi-unit franchising is positively related to franchise system density (Sanchez et al. 2006). The data also supports the hypotheses that a larger franchise system and franchise systems operating in service sectors make relatively extensive use of multiunit franchising. The findings of Weaven \& Herington (2007) suggest that less mature and small franchise systems generally use single-unit franchising and less sophisticated HRM policies and, on the other hand, large and mature franchise systems generally use multi-unit franchising and more sophisticated HRM policies. It was also argued that multi-unit franchising networks share information more effectively and are more likely to adopt system-wide adaptations as compared to single unit franchisees. The results of a recent study in Spain revealed that the franchisors use economic rents to self-enforce the behavior of the franchisees (Lopez-Bayon and Lopez-Fernandez 2008). Moreover, the authors found that ex-post rents are higher in case of multi-unit franchising as compared to single unit franchising.

\section{DISCUSSION AND DEVELOPMENT OF MODEL}

In this section, we discuss the methodological and theoretical deficits and review the relevant empirical literature in the agency theory, resource based and organizational capability view, and transaction cost theory frameworks. Then we develop hypotheses for the empirical test.

\section{Methodological Issues}

As discussed in previous sections, there is a limited number of studies in the area of multi-unit franchising. A significant proportion of these studies use convergent or "loosely structured" interviews (Bradach 1995; Weaven \& Frazer 2006; Weaven \& Frazer 2007a; Weaven \& Frazer 2007b; Weaven \& Herington 2007). However, the validity and generalizabilty of results obtained through convergent interviews can be questioned. Therefore, the contribution of existing multi-unit franchising research to the franchising literature cannot be easily evaluated. Moreover, a number of existing studies (for example Robicheaux et al. 1994; Bradach 1995; Kaufmann \& Dant 1996; Kalnins \& Lafontaine 2004; Kalnins \& Mayer 2004; Gruenhagen \& Mittelstaedt 2005; Weaven \& Frazer 2006) use data from the US fast food sector only, which results in tenuous generalizability of the findings of these studies. This empirical deficit requires large-scale statistical analysis that also investigates the multi-unit franchising ownership strategy in different industries.

\section{Transaction Cost Theory}

Klein (1980) argues that system-specific investments increase the risk of shirking on the part of the beneficiary of such investments. If the franchisee has undertaken high system-specific investments, he is strongly dependent on to the franchise system and, in such a situation, the franchisor can easily show opportunistic behavior. On the other hand, due to high system-specific investments of the franchisor, a double hostage effect arises which 
increases the self-enforcing range of contract and therefore prevents both partners from opportunistic behavior (Williamson 1983; Klein 1995). Due to the higher specific investments, multi-unit franchisees are more motivated to show cooperative behavior, thus the frequency of use of disciplinary measures should be lower in the multi-unit franchising system compared to the single-unit franchising system. Bercovitz (2003) shows that multi-unit franchising significantly reduces the rate of litigation between franchisee and franchisor and the termination rate is significantly low in the systems.

\section{Specific Investments}

The impact of specific investment on the choice of ownership strategy between single and multi-unit franchising has not been examined in the franchise literature. Specific investments of the franchisee have two effects on the governance structure:

1. Bonding Effect (Williamson 1983, Klein 1995) - If the franchisee is a multi-unit owner, he has to undertake higher specific investments to open up the local network compared to single-unit franchising. On the other hand, the additional investment costs decrease with the number of local units; hence, he can realize a given level of quasi rents with lower costs for specific investments. This bonding effect increases the franchisee's dependency, hence his motivation to behave cooperatively.

2. Screening Effect (Dnes 1992) - Multi-unit franchising as an area development arrangement reduces the recruitment risk for franchisor due to its screening effect in the pre-contract period. Franchisors can better screen the potential franchisees because it is likely that candidates with higher financial and entrepreneurial capabilities will choose the multi-unit ownership arrangement. Consequently, we can derive the following proposition: The higher the bonding and screening effect of specific investments under multi-unit franchising compared to single-unit franchising, the higher the tendency toward multi-unit franchising.

P1: $\quad$ Franchisee's system specific investments are positively related with the franchisor's tendency to use multi-unit franchising.

\section{Uncertainty}

Although Williamson (1975) extensively discussed the role of uncertainty/complexity for the choice of organization form, recent research on the choice of governance mechanism does not investigate the influence of this determinant on the governance form. Single-unit franchisees perform better in terms of local responsiveness and they are able to promptly react to the local market changes as compared to multi-unit franchisees (Bradach 1995). The higher environmental uncertainty, the more relevant is the local market knowledge of the single-unit franchisee for the success of the local outlet, and lower is the tendency toward multi-unit franchising. However, the case may not be the same for both types of multi-unit franchising; i.e. sequential and area development arrangements. Generally, the franchisors use sequential multi-unit franchising as a "carrot" to motivate the franchisees for higher performance (Bercovitz 2003) and the additional units are awarded to the franchisee who has shown outstanding performance. Sequential multi-unit franchisees have relatively higher local market know-how as compared to area developers due to their experience in the local market. Hence, we come up with the following proposition:

\section{P2: Market uncertainty is negatively related with franchisor's tendency to use area development arrangement}

\section{Resource Scarcity and Organizational Capabilities}

\section{Resource Scarcity Theory}

The resource-based view argues that firm-specific resources result in long-term higher performance and hence, is a competitive advantage. The firm achieves competitive advantage if its resources and capabilities are rare or difficult to imitate and substitute (Barney 1991). The resource scarcity theory explains that franchisors use franchising to overcome the scarcity of resources; i.e. capital, managerial resources and local market assets. If we take into consideration the capital acquisition perspective, multi-unit franchising has a relative advantage over 
single-unit franchising for the franchisor (Kaufmann and Dant 1996). The multi-unit franchisees are larger partners and have better access to capital that enables a higher rate of system growth. Empirical studies show that multi-unit franchising and system growth are positively related (Bradach 1995; Kaufmann \& Kim 1995; Kaufmann \& Dant 1996). It is also argued that franchise systems with a higher growth rate are in a better position to attract high quality and larger franchisees to offer them multi-unit franchising (Kaufmann \& Kim 1995). In contrast to the predictions of resource scarcity theory, the use of multi-unit franchising increases with the size and maturity of the franchise system (Sachel et al. 2006; Weaven \& Frazer 2007b; Weaven \& Herington 2007).

According to the resource-scarcity view, the franchisors do not possess enough local market information and financial resources at the beginning of their life-cycle (e.g. Dant and Kaufmann 1996; Oxenfeldt and Kelly 1969). Franchising enables them to overcome this scarcity problem. The question to ask is: Does multi-unit franchising additionally mitigate this scarcity problem for the franchisor and hence contribute to explain the tendency toward franchising? Local market knowledge can be more efficiently acquired by single-unit franchisees compared to employees of the multi-unit network because the single-unit entrepreneur (as residual claimant) has higher entrepreneurial capabilities and is more motivated to exploit the profit opportunities at the local market environment than the multi-unit employee.

P3: $\quad$ The importance of local market know-how of the franchisee is negatively related with the franchisor's tendency toward multi-unit franchising.

Furthermore, financial resource scarcity of the franchisor may result in higher franchising to support the expansion of the system. Multi-unit franchising offers additional growth opportunities for the franchisor compared to the single-unit franchising strategy because multi-unit franchisees are often less constraint to finance the local outlets compared to the single-unit franchisees.

P4: $\quad$ Financial resource scarcity, measured by initial fees and initial investments, is positively related with the tendency to use multi-unit franchising.

\section{Organizational Capabilities}

Organizational capabilities can be defined as a bundle of resources that create synergies and sustainable competitive advantage (Madhok 1997). Multi-unit franchising increases the organizational capabilities and hence, the competitive position of the system. System uniformity, system-wide adaptations, and system corporatisation are examples of organizational capabilities. The franchisors who place greater emphasis on system uniformity and corporatisation and consider system-wide adaptations important for the success of the business, are more likely to use multi-unit franchising (Weaven \& Frazer 2007a, b). In addition, multi-unit franchising increases the knowledge transfer capability of the system because the franchisors delegate some knowledge transfer tasks to the local networks.

Firm-specific resources and organizational capabilities of the franchising firm increase the residual income of the network. According to March (1991), the organization design of the firm is characterized by two capabilities: exploration and exploitation capabilities. The question to ask is: Can the franchising network realize higher exploration and exploitation capabilities by using multi-unit franchising compared to single-unit franchising? (a) Exploitation capabilities refer to the efficient use of the given knowledge in the network; they consist of monitoring capabilities, knowledge transfer capabilities, and human resource capabilities. Multi-unit franchising results in higher monitoring capabilities for the network compared to a system with single-unit franchising because the franchisor can delegate the monitoring task to the franchisee that has special market knowledge and realizes economies of monitoring. Simultaneously, additional agency problems between the local franchisees and its outlet managers are mitigated because of the higher incentive effect of the multi-unit franchising compared to single-unit franchising. In addition, the knowledge transfer capacity is higher under multi-unit franchising compared to singleunit franchising because the franchisor may delegate some knowledge transfer task to the mini-networks. Finally, due to the screening effect of multi-unit franchising, the entrepreneurial capabilities of the network may increase. (b) Exploration capabilities primarily refer to the higher innovation capabilities of the networks. Multi-unit franchising improves the capabilities of the system to achieve growth and excel in innovation. Especially, testing of new ideas in 
the mini-networks and then transferring it to the whole system results in higher dynamic capabilities of the system. These capabilities enable a permanent increase of the brand name value. As a result, we can say that monitoring, knowledge transfer, human resources and innovation capabilities are more important for the creation of residual income of the system, the higher the system-specific know-how is.

\section{P5: $\quad$ System-specific know-how is positively related with the franchisor's tendency to use multi-unit} franchising.

\section{Agency Theory}

Kaufmann and Dant (1996) argue that it is difficult to explain multi-unit franchising from agency theory perspectives. On the other hand, some researchers argue that multi-unit franchising can address a number of agency problems in a more effective way compared to single-unit franchising (Garg and Rasheed 2003). Especially multiunit franchisees are better motivated to reduce the monitoring cost and increase the monitoring efficiency. It has been shown that franchisors are motivated by agency cost minimization, system-wide uniformity, reward strategies, and geographical proximity to adopt multi-unit franchising (Weaven \& Frazer 2007a). Shirking on quality would affect the multi-unit franchisee's business in the local network and ultimately his profitability (Fladmoe and Jacque 1995). Sequential multi-unit franchising can be used as incentive device to franchisees for higher performance. The franchise systems with a higher number of geographically contiguous units are more likely to use a higher proportion of multi-unit franchising (Kalnins and Lafontaine 2004; Kalnins \& Mayer 2004; Weaven \& Frazer 2007a).

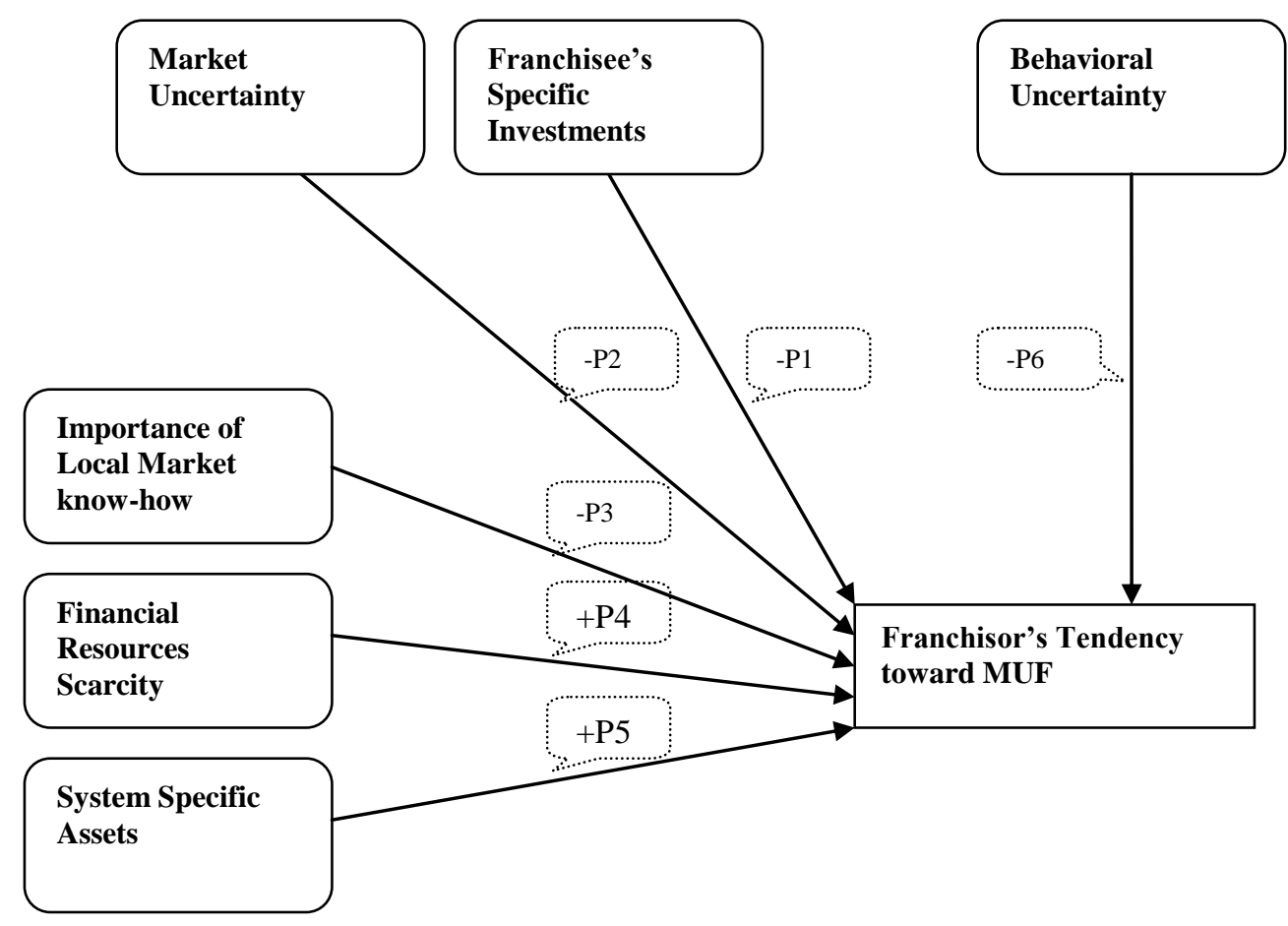

As discussed above, many studies apply the agency-theoretical framework to investigate franchising. According to the agency theory (e.g. Brickley et al. 1991, Lafontaine 1992), agency costs result from behavioral uncertainty due to shirking and free-riding of the network partners. The incentive effect of multi-unit franchising may mitigate these agency problems. Higher motivation of the franchisees at the local outlets results in lower shirking and free-riding under multi-unit franchising compared to single-unit franchising.

P6: Behavioral uncertainty, due to shirking and free riding, is positively related with the tendency towards multi-unit franchising. 
We plan to empirically test the proposed model in the near future by using data from multiple industries. However, the operationalization of some constructs, for example, local market know-how and behavioral uncertainty, could be a challenging task.

\section{CONCLUSION}

Based upon theoretical deficits in the multi-unit franchise literature, we develop a model containing a set of six propositions for the explanation of multi-unit franchising as franchisor's ownership strategy. The propositions are derived from agency, transaction costs and resource-based theory. The next step is to empirically test the proposed model. The empirically supported model would contribute toward the franchising literature by addressing the current research gap. In addition, the proposed model would have managerial implications as well and would provide the guidelines to business executives to use multi-unit franchising as an ownership strategy.

\section{AUTHOR INFORMATION}

Dildar Hussain obtained his MBA degree (with distinction) in year 2001 and has been working in industry for almost 5 years. He was awarded fellowship for his PhD studies by Higher Education Commission (HEC) Pakistan, under the project "Overseas Scholarship Scheme for PhD in Selected Fields" in 2007 and presently he is working as a PhD candidate at Center for Business Studies, University of Vienna, Austria. His area of research interest includes franchising, strategic networks, and corporate governance.

Muhammad Zafar Yaqub is a doctoral scholar at University of Vienna, Austria. He received his Master degree in Business Administration (with distinction) from Bahauddin Zakariya University, Multan in 1995. Afterwards, he received his Master degrees in Economics (1999), and Political Science (2005) from The Islamia University of Bahawalpur. $\mathrm{He}$ is serving as Assistant Professor of Management Sciences in The Islamia University of Bahawalpur.

\section{REFERENCES}

1. Barney, J., Firm Resources and Sustained Competitive Advantage, Journal of Management, Vol. 17, Vol. 1, pp. 99-120, 1991.

2. Bates, T., Survival Patterns Among Newcomers to Franchising, Journal of Business Venturing, Vol. 13, pp. 113-130, 1998.

3. Bercovitz, Janet E.L., The option to expand: The use of multi-unit opportunities to support selfenforcement agreements in franchise relationships, Proceedings of $1^{\text {st }}$ International conference on Economics and Management of Networks, Vienna, Austria, 2003.

4. Bradach, J. L., Chains within Chains: The Role of Multi-Unit Franchisees, Journal of Marketing Channels, Vol. 4 No.1/2, pp. 65-81, 1995.

5. Brickley, J. A. and Dark, F. H and Weisbach, M. S., An Agency Perspective on Franchising, Financial Management, Vol. 20, pp. 27-35, 1991.

6. Business Week, What's wrong with franchising?, 14 August, "Frontier" Section, pp. F44-F50, 2000

7. Dant, R. P., Kacker, M., Coughlan, A. T., and Emerson, J.,. "A Cointegration Analysis of the Correlates of Performance in Franchised Channels." in Economics and Management of Networks: Franchising Networks, Cooperatives, Joint Ventures and Alliances. Eds. Cliquet, G., Hendrikse, G., Tuunanen, M. and Windsperger, J., Springer Publishing, Heidelberg, Germany, 2007.

8. $\quad$ Dnes, A. W., Franchising: A case-study approach. Avebury, Brookfield, UK, 1992

9. Fladmoe-Lindquist, K., and Jacque, L.L., Control modes in international service operations: The propensity to franchise, Management Science, Vol 41 No. 7, pp. 1238-1249, 1995.

10. Garg, V. K. and Rasheed, A. A., International multi-unit franchising: an agency theoretic explanation, International Business Review, Vol. 12, No. 329-348, 2003.

11. Grag, V. K., Rasheed, A. A., and Priem, R. L. 2005. "Explaining Franchisor's Choices of Organization Forms within Franchise Systems." Strategic Organization, 3 (2): 185-217.

12. Gruenhagen, M. and Dorsch, M. J. 2003. "Does the Franchisor Provide Value to Franchisees? Past, Current and Future Value Assessment of Two Franchisee Types.” Journal of Small Business Management 41(4): 366-84. 
13. Gruenhagen, M. and Mittelstaedt, R. A. 2005. "Entrepreneurs or Investors: Do Multi-unit Franchisees Have a Different Philosophical Orientations.” Journal of Small Business Management 43(3): 207-25.

14. Kanins, A. and Lafontaine, F. 2004. "Multi-unit ownership in franchising: evidence from the fast-food industry in Texas." The Rand Journal of Economics 35(4): 747-61.

15. Kalnins, A. and Mayer, K. J. 2004, "Franchising, Ownership, and Experience: A Study of Pizza Restaurant Survival.” Management Science 50(12): 1716-28.

16. Kaufmann, P.J 1992. "The impact of Managerial Performance Decay on Franchisor's Store Allocation Strategies." Journal of Marketing Channels 1(4): 51-79.

17. Kaufmann, P. J., The state of research in franchising, Franchising Research: An International Journal, Vol. 1, No. 1, pp 4-7, 1996.

18. Kaufmann, P. J., and Dant, R. P., Multi-unit Franchising: Growth and Management Issues, Journal of Business Venturing, Vol. 11, Vol. 5, pp. 343-358, 1996.

19. Kaufmann, P. J., and Dant, R. P., Franchising and the Domain of Entrepreneurship Research, Journal of Business Venturing, Vol. 14, pp. 5-16, 1998.

20. Kaufmann, P. J. and Kim, S. H., Master Franchising and System Growth Rates, Journal of Marketing Channels, Vol. 4, No. 1, pp. 49-64, 1995.

21. Klein, B., Transaction Cost Determinants of "Unfair" Contractual Arrangement, American Economic Review, Vol. 70, pp. 356-362, 1980.

22. Klein, B., The economics of franchise contracts, Journal of Corporate Finance, Vol. 2, pp. 9-37, 1995.

23. Lafontaine, F., Agency Theory and Franchising: Some Empirical Results, RAND Journal of Economics, Vol. 23, No. 2, pp. 2632-83, 1992.

24. Lopez-Bayon, S. and Lopez-Fernandez, B., Do Multi-unit Franchisees Gain More?, Proceedings of $22^{\text {nd }}$ Annual International Society of Franchising Conference, Saint-Malo, France, 2008.

25. Madhok, A., Cost, Value and Foreign Market Entry Model: The Transaction and Firm, Strategic Management Control, Vol. 18, pp. 39-61, 1997.

26. March, J.G., Exploration and Exploitation in Organizational Learning, Organization Science Vol. 2, No. 1, pp. 71-87, 1991.

27. Oxenfeldt, A.R. and Kelly, A.O., Will successful franchise systems ultimately become wholly owned chains?, Journal of Retailing, Vol. 44, No. 4, pp. 69-84, 1969.

28. Robicheaux, R. A., Dant, R. P. and Kaufmann, P. J., Multiple Unit Franchising in the Fast Food Industry in the United States: Incidence and Operating Characteristics, Proceedings of $8^{\text {th }}$ Annual Society of Franchising Conference, Las Vegas, USA, 1994.

29. Sanchez, R. S., Saurez, I. and Vazquez, L. 2006. "Ownership strategies in franchise networks: Multi-unit versus single unit franchising”, proceedings of International Federation of Scholarly Associations of Management VII World Conference, Berlin, Germany, 2006.

30. Wadsworth, F. and Morgan, K. B., Multi-unit Franchisee Ownership Study" Proceedings of $17^{\text {th }}$ Annual International Society of Franchising Conference, San Antonio, USA, 2003.

31. Weaven, S. and Frazer, L., Multi Unit Franchising: Australian Revelations, Proceedings of $18^{\text {th }}$ International Society of Franchising Conference, Las Vegas, USA, 2004.

32. Weaven, S. and Frazer, L., Investment Incentives for Single and Multiple unit Franchisees, Qualitative Market Research: An International Journal, Vol. 9, No. 3, pp. 225-242, 2006.

33. Weaven, S. and Frazer L., Expansion Through Multiple Unit Franchising: Australian Franchisors Reveal their Motivations, International Small Business Journal Vol. 25, No. 2, pp. 173-205, 2007a.

34. Weaven, S. and Frazer L., Mature franchise systems use multiple unit franchising to leverage learning economies and sustain system wide growth, Asia Pacific Journal of Marketing and Logistics, Vol. 19. No. 2, pp. 107-26, 2007b.

35. Weaven, S. and Herington, C., Factors influencing governance and human resource management within services franchising networks, Journal of Management \& Organization, Vol. 13, No. 2, pp. 126-44, 2007.

36. Williamson, O. E., Markets and Hierarchies: Analysis and Antitrust Implications - A Study in the Internal Organizations, The Free Press, New York, 1975.

37. Williamson, O. E., Credible Commitments: Using Hostages to Support Exchange, American Economic Review, Vol. 73, No. 4, pp. 519-540, 1983.

38. Williamson, O. E., The Economic Institutions of Capitalism, The Free Press, New York, USA, 1985.

39. Zeller, R. E., Alchabal, D. D. and Brown, L. A., Market Penetration and Locational Conflict in Franchise Systems, Decision Science Vol. 11, No. 1, pp. 58-80, 1980. 